\title{
Efficiency of introducing a steam screw-rotor machine to the heating power plant circuit
}

\author{
Rita Rotach ${ }^{1, *}$, Yuri Vankov ${ }^{1}$, and Shamil Ziganshin ${ }^{1}$ \\ ${ }^{1}$ Kazan State Power Engineering University, Kazan, Russia
}

\begin{abstract}
The aim of the work is to increase the efficiency of the Nizhnekamsk CHPP-1 (combined heat and power plant) by introducing a steam screw-rotor machine (SSRM) into the thermal circuit. It is proposed to exclude the passage of steam from the exit of the turbine through the pressure reduction and desuperheating station (PRDS) for own needs. Superheated steam is diverted to be sent to a steam screwrotor machine installed parallel to the PRDS. This technical solution will allow to obtain steam used in low pressure deaerators, as well as electricity for own needs of the CHPP. The article presents the operating parameters, as well as the calculation results of the backpressure turbine. A feasibility study was carried out for the introduction of SSRM into the plant's thermal circuit: the equivalent fuel and electricity savings for own needs were calculated, as well as the payback period of the project for introducing a steam screwrotor machine. In the course of the calculations, the following results were obtained: a decrease in the specific consumption of equivalent fuel for the production of $1 \mathrm{kWh}$ of electricity - by $1.9 \mathrm{~g}$; saving of equivalent fuel during the implementation of the SSRM will be 13 tons per year, which also entails a reduction in emissions into the environment; Electricity production for own needs is $8100 \mathrm{kWh}$, the payback period for the project to introduce a steam screw machine in the thermal circuit of a thermal power plant is 5 years.
\end{abstract}

\section{Introduction}

The aim of the work to find out the possibility of parallel production of $0.12 \mathrm{MPa}$ auxiliary steam at the Nizhnekamsk CHPP-1 and $1250 \mathrm{~kW}$ of electric energy with a frequency of $50 \mathrm{~Hz}$ supplied to the CHPP auxiliary electric bus. To achieve this goal, it is proposed to introduce a steam screw-rotor machine into the thermal circuit of the heating power station, as well as evaluate the economic effect of this technical solution [1-2].

Steam is used from the extraction of cogeneration turbines is used at the Nizhnekamsk CHPP-1 to obtain $0.12 \mathrm{MPa}$ steam for heating demineralized water in low pressure deaerators (LPD). In winter, with a lack of extraction from these turbines, steam is used from regulated industrial steam extraction of the counterpressure turbine. Superheated steam passes after the turbine through a pressure reduction and desuperheating station PRDS 14/1.2 (the parameters are shown in Table 1) with its pressure and temperature reducing there. To exclude the steam reduction and to use the existed differential pressure, it is proposed to introduce a steam screw-rotor machine (SSRM) in parallel with PRDS 14/1.2. This technical solution will allow simultaneously receiving $0.12 \mathrm{MPa}$ steam and $1,250 \mathrm{~kW}$ of electrical energy [3-7].

The SSRM is developed in Russia. It is a unique equipment without any foreign analogues. The design of the SSRM, its assemblies and systems is covered with about 25 patents in Russia and abroad [8].

Table 1. Technical parameters of the PRDS

\begin{tabular}{|c|c|c|c|}
\hline \multirow{2}{*}{ Name } & \multirow{2}{*}{ Rated capacity, t/h } & \multicolumn{2}{|c|}{$\begin{array}{c}\text { Superheated/desuperheated steam } \\
\text { parameters }\end{array}$} \\
\hline & & Pressure, atm (MPa) & $\begin{array}{l}\text { Temperature, } \\
\text { degrees Celsius }\end{array}$ \\
\hline PRDS 14/1.2 & 40 & $14 / 1.2(1.4 / 0.12)$ & $246 / 130$ \\
\hline
\end{tabular}

The steam screw-rotor machine (SSRM) is a volumetric rotary machine. According to its operation principle, it is an inverted dry screw compressor.
Structurally, the SSRM consists of a housing where two working bodies - rotors are located with sliding bearings, seals and other components and parts. The power unit

\footnotetext{
* Corresponding author: rita-nurkaeva@mail.ru
} 
consists of a steam screw-rotor machine (SSRM) and a generator connected through a compensating sleeve and installed on a concrete foundation with supports, the generator frame and base plates [9-12].

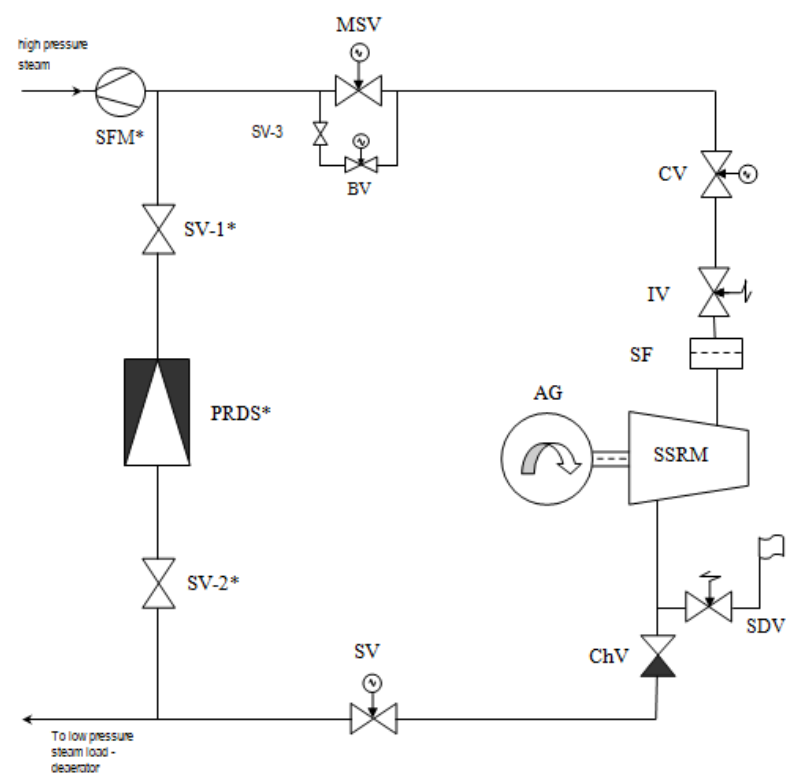

Fig.1. Thermal circuit if the SSRM

SSRM - steam screw-rotor machine, AG - electrical generator, $\mathrm{CV}$ - control valve, MSV - main steam valve, BV - bypass steam valve, $\mathrm{SV}$ - steam valve, IV - emergency isolation valve, ChV - check valve, SDV - steam dump valve, SF steam filter, SFM - steam flow meter, PRDS - pressure reducing and desuperheating station

\section{Methods}

The used methods include computational mathematics, heat and mass transfer theory, methods of technical and economic calculations in the power energy industry, and thermodynamic analysis of power plants. Application software packages were used for calculations and plotting graphical dependencies.

A thermal calculation of the backpressure turbine was performed to determine the parameters of the steam at the inlet to the steam screw-rotor machine. The calculation followed the method presented in [13-15]. The calculation results are shown in Table 2.

Table 2. Steam parameters at the extraction stages

\begin{tabular}{|c|c|c|c|}
\hline Control point & $\mathbf{P}_{\mathrm{s}}, \mathbf{M P a}$ & $\mathbf{T}_{\mathrm{s}},{ }^{\circ} \mathrm{C}$ & $\begin{array}{c}\mathbf{h}_{\mathrm{s}} \\
\mathbf{k J} / \mathbf{k g}\end{array}$ \\
\hline $\begin{array}{c}0 \text { (steam parameters at } \\
\text { the turbine inlet) }\end{array}$ & 12.75 & 555 & 3485 \\
\hline $\begin{array}{l}0 " \text { (steam parameters at } \\
\text { the 1st turbine stage) }\end{array}$ & 12.4 & 552 & 3485 \\
\hline $\begin{array}{l}1 \text { (steam parameters in } \\
\text { the } 1 \text { st regenerative } \\
\text { steam extraction) }\end{array}$ & 3.03 & 353 & 3122 \\
\hline $\begin{array}{l}2 \text { (steam parameters in } \\
\text { the } 2 \text { nd regenerative } \\
\text { steam extraction) }\end{array}$ & 1.95 & 299 & 3024 \\
\hline $\begin{array}{l}3 \text { (steam parameters in } \\
\text { regulated industrial } \\
\text { steam extraction) }\end{array}$ & 1.4 & 246 & 2926 \\
\hline
\end{tabular}

The feasibility study of the SSRM implementation carried out in accordance with the following method:

Determination of SSRM electric power:

$$
N_{e l}=D \cdot\left(h_{1}-h_{2}\right) \cdot \eta=11,3 \cdot(2926-2741) \cdot 0,62=1273 \mathrm{~kW}
$$

where

$h_{1}$ is steam enthalpy at the SSRM inlet, $\mathrm{kJ} / \mathrm{kg}$;

$h_{2}$ is steam enthalpy at the SSRM outlet, $\mathrm{kJ} / \mathrm{kg}$.

$D$ is the steam flow rate thought the SSRM, $\mathrm{kg} / \mathrm{s}$.

Complete heat consumption for the turbine unit P100-130/15

$$
Q_{\mathrm{t}}=D_{0} \cdot\left(h_{0}-h_{\mathrm{f}}\right)=208,3 \cdot(3485-993,3)=519021 \mathrm{~kW}
$$

where

$h_{0}$ is steam enthalpy at the turbine inlet, $\mathrm{kJ} / \mathrm{kg}$;

$h_{f}$ is feedwater enthalpy at the $\mathrm{HPH}, \mathrm{kJ} / \mathrm{kg}$.

Heat consumption for the auxiliary loads when using the PRDS or SSRM:

$$
\begin{aligned}
& Q_{p r}=D_{p} \cdot\left(h_{s e}-h_{d}\right)-D_{P R D S} \cdot\left(h_{3}-h_{P R D S}^{\prime}\right)= \\
& =175,52 \cdot(2926-624,8)-11,1 \cdot(2926-2741)=401853 k W
\end{aligned}
$$

Dpr is steam flow rate for the production, $\mathrm{kg} / \mathrm{s}$;

hse is steam parameters in regulated industrial steam extraction, $\mathrm{kJ} / \mathrm{kg}$;

hd is the feedwater temperature after the deaerator, $\mathrm{kJ} / \mathrm{kg}$;

DPRDS is the steam flow rate at the PRDS, $\mathrm{kg} / \mathrm{s}$;

Heat consumption of the power generating turbine using PRDS or SSRM:

$$
Q_{\mathrm{t}}^{\mathrm{el}}=Q_{\mathrm{t}}-Q_{\mathrm{pr}}=519021-401853=117168 \mathrm{~kW}
$$
PRDS:

The efficiency factor of power generation when using

$$
\eta_{\text {prds }}=\frac{N_{\mathrm{el}}}{Q_{\mathrm{t}}^{\mathrm{el}}}=\frac{111322}{117168}=0.95
$$

The efficiency factor of power generation of the power unit when using PRDS:

$$
\eta=\eta_{\text {prds }} \cdot \eta_{\text {pg }} \cdot \eta_{\text {tr }}=0.95 \cdot 0.93 \cdot 0.986=0.87
$$

Specific consumption of equivalent fuel for power generation when using PRDS:

$$
b_{\mathrm{e}}^{\mathrm{g}}=\frac{123}{\eta}=\frac{123}{0.87}=141.38 \frac{\mathrm{g}}{\mathrm{kW} \cdot \mathrm{h}}
$$

The efficiency factor of power generation when using SSRM

$$
\eta_{\text {SSRM }}=\frac{N_{\text {el }}+N_{\text {SSRM }}}{Q_{\mathrm{t}}}=\frac{111322+1250}{117168}=0.96
$$

The efficiency factor of power generation of the power unit when using SSRM:

$$
\eta=\eta_{\mathrm{SSRM}} \cdot \eta_{\mathrm{pg}} \cdot \eta_{\mathrm{Tr}}=0.96 \cdot 0.93 \cdot 0.986=0.88
$$

Specific consumption of equivalent fuel for power generation when using SSRM:

$$
b_{\mathrm{e}}^{\mathrm{g}}=\frac{123}{\eta_{\mathrm{c}}^{{ }^{9}}}=\frac{123}{0.88}=139.77 \frac{\mathrm{g}}{\mathrm{kw} \cdot \mathrm{h}} .
$$

The difference in the specific consumption of equivalent fuel for power generation with using PRDS and SSRM: 


$$
\Delta b_{\mathrm{e}}^{\mathrm{g}}=141,38-139,77=1.61 \frac{\mathrm{g}}{\mathrm{kw} \cdot \mathrm{h}}
$$

The planned operation of the SSRM is 6,480 hours per year.

Annual savings in specific fuel consumption:

$$
\Delta b_{\mathrm{e}}^{\text {year }}=\Delta b_{\mathrm{e}}^{\mathrm{g}} \cdot N=1,61 \cdot 8100=13.041 \text { tons }
$$

CHPP auxilirary power generation with SSRM:

$$
N=N_{e l} \cdot n_{h}=1,25 \cdot 6480=8100 \mathrm{MW} \cdot \mathrm{h}
$$

$N_{e l}$ - CHPP auxilirary power generation with SSRM, $n_{h}$ - running hours.

Saving money per year will be:

$$
E=N \cdot P=8100 \cdot 14,71=119151 \text { USD }
$$

$\mathrm{N}$ - power generation per year, thousand $\mathrm{kW} \cdot \mathrm{h}$,

$\mathrm{P}$ - the price of the auxiliary power energy, USD/MW'h (we take the actual cost of purchased electric power for $\mathrm{CH}$ at Nizhnekamsk CHPP-1 for calculation according to $2020 \mathrm{P}=14,71 \mathrm{USD} / \mathrm{MW} \cdot \mathrm{h}$ )

Profit $=E-C_{E R}=119151-2629=116522$ USD per year where

$C_{E R}$-costs of the equipment repairs, 2629 US dollar.

\section{Results and Discussion}

An estimated calculation of the economic efficiency of the SSRM implementation is given in tables 3 and 4 .

Table 3. Estimated calculation of the economic efficiency of the SSRM implementation for the period 2020-2026.

\begin{tabular}{|c|c|c|c|c|c|c|c|}
\hline Year & $\mathbf{2 0 2 0}$ & $\mathbf{2 0 2 1}$ & $\mathbf{2 0 2 2}$ & $\mathbf{2 0 2 3}$ & $\mathbf{2 0 2 4}$ & $\mathbf{2 0 2 5}$ & $\mathbf{2 0 2 6}$ \\
\hline $\begin{array}{c}\text { Electricity savings on own } \\
\text { needs, thousand kWh/year }\end{array}$ & 8100 & 8100 & 8100 & 8100 & 8100 & 8100 & 8100 \\
\hline $\begin{array}{c}\text { Price of kWh, including } \\
\text { indexation, USD/thousand } \\
\text { kWh }\end{array}$ & 14.71 & 15.17 & 15.64 & 16.12 & 16.62 & 17.14 & 17.67 \\
\hline $\begin{array}{c}\text { Savings on own needs, } \\
\text { thousand USD / year }\end{array}$ & 119151 & 122877 & 126684 & 130572 & 134622 & 138834 & 143127 \\
\hline $\begin{array}{c}\text { Average indexation factor } \\
\text { for the electricity price }\end{array}$ & 1.031 & 1.031 & 1.031 & 1.031 & 1.031 & 1.031 & 1.031 \\
\hline $\begin{array}{c}\text { Average annual repair costs } \\
\text { USD }\end{array}$ & 2629 & 2706 & 2846 & 2962 & 3093 & 3186 & 3294 \\
\hline $\begin{array}{c}\text { Construction price index } \\
\text { growth rate } \\
\text { (repairs) }\end{array}$ & 1.043 & 1.041 & 1.043 & 1.04 & 1.04 & 1.036 & 1.034 \\
\hline Total savings, USD/year & 166152 & 120171 & 123838 & 127610 & 131529 & 135648 & 139833 \\
\hline
\end{tabular}

Table 4. Estimated calculation for the SSRM implementation feasibility for the period 2027-2030.

\begin{tabular}{|c|c|c|c|c|}
\hline Year & $\mathbf{2 0 2 7}$ & $\mathbf{2 0 2 8}$ & $\mathbf{2 0 2 9}$ & $\mathbf{2 0 3 0}$ \\
\hline $\begin{array}{c}\text { Electricity savings on own needs, thousand } \\
\text { kWh/year }\end{array}$ & 8100 & 8100 & 8100 & 8100 \\
\hline $\begin{array}{c}\text { Price of kWh, including indexation, } \\
\text { USD/thousand kWh }\end{array}$ & 18.21 & 18.78 & 19.36 & 19.96 \\
\hline Savings on own needs, thousand USD / year & 147501 & 152118 & 156816 & 161676 \\
\hline $\begin{array}{c}\text { Average indexation factor for the electricity } \\
\text { price }\end{array}$ & 1.031 & 1.031 & 1.031 & 1.031 \\
\hline $\begin{array}{c}\text { Average annual repair costs USD } \\
\text { Construction price index growth rate } \\
\text { (repairs) }\end{array}$ & 3418 & 3526 & 3650 & 3774 \\
\hline Total savings, USD/year & 1.034 & 1.035 & 1.035 & 1.033 \\
\hline
\end{tabular}

Table 5.SSRM payback period

\begin{tabular}{|c|c|c|}
\hline No & Parameter & Value \\
\hline 1 & Net present value (NPV), USD & 134117 \\
\hline 2 & Internal rate of return (IRR), \% & 14.09 \\
\hline 3 & Profitability index (PI) & 1.19 \\
\hline 4 & Payback period (PBP), year & 4.89 \\
\hline
\end{tabular}

The above calculations show that the payback period of a project to upgrade the thermal circuit of Nizhnekamsk CHPP -1 based on the SSRM will be 5 years. The economic effect in 2020 will be 166,152 USD and will grow from year to year, given the change in the indexation factor.

\section{Conclusions}

In this paper, we consider the option of upgrading the thermal circuit of the Nizhnekamsk CHPP -1 with the installation of a $1300 \mathrm{~kW}$ steam screw-rotor machine. The proposed solution will allow getting $0.12 \mathrm{MPa}$ auxiliary steam (including for the LPD) and at the same time additionally generating $1.25 \mathrm{MW}$ of electricity by 
eliminating the need for steam throttling through a 14/1.2 atm PRDS. A feasibility study was also carried out for the SSRM into the thermal circuit of the CHPP. Savings of equivalent fuel in case the SSRM implementation were defined along with the plant auxiliary power saving, as well as the payback period of the proposed solution.

\section{References}

1. S.R. Berezin, V.M. Borovikov, V.I. Vedaiko, Power Industry of Tatarstan, 1(13) (2009)

2. R.M. Guzairov, R.M. Akhmetshin, Engineering systems, 2 (2009)

3. S.S. Semyonov, A.M. Shevchenko, Thermal calculation of the steam turbine (1975)

4. J. Li, P. Gang, Applied Energy, 165 (2016)

5. Nikolov, A. Brümmer, Energies, 18 (2017)

6. I K Smith, N Stosic, E Mujic, A Kovacevic, Journal of Process Mechanical Engineering, 5 (2014)

7. A. Giuffrida, Applied Energy, 193 (2017)

8. G. Bianchi, S. Kennedy, O. Zaher, S. A. Tassou, J. Miller, H. Jouhara, International Journal of Refrigeration, 88 (2018)

9. G-D. Xia, Ye-Q. Zhang, Yu-T. Wu, Ch-F. Ma, WN. Ji, Applied Thermal Engineering, 87 (2015)

10. M.Astolfi, Energy Procedia, 69 (2015)

11. R. Sen, S.C. Bhattacharyya, Renewable Energy, 62 (2014)

12. S.M. Orosz, V.A.Mueller, J.B. Dechesne, F.H. Hemond, Journal of Engineering for Gas Turbines and Power, 135 (2013)

13. O. Dumont, A. Parthoens, R. Dickes, V. Lemort, Energy, 5 (2018)

14. D.Ziviani, S.Gusev, S. Lecompte, Applied Energy, 181 (2016)

15. O. Dumont, R. Dickes, V. Lemort, ORC power systems, 2 (2017). 